\title{
European career guidance policy: A focus on subtle regulatory mechanisms
}

\author{
Anki Bengtsson
}

Received: 1 June 2015 / Accepted: 10 July 2015 / Published online: 14 August 2015

(C) The Author(s) 2015. This article is published with open access at Springerlink.com

\begin{abstract}
Current political strategy to reform career guidance systems in Europe is regulated by subtle practices. Using the governmentality perspective, the purpose of this article is to make sense, in theoretical terms, of governmental reason and mechanisms in reshaping of career guidance systems. The investigation draws attention to mechanisms and practices such as monitoring and evaluation which indirectly operate in the policy process to make career guidance systems amenable for management. Drawing empirically on European policy texts, the analysis focuses on policy use of "good practice" and provision of data, which work upon the attitude to performance improvement and self-improvement. This article seeks to elucidate that incentive for learning from "good practice" and evaluation is related to the present form of governance by indirect mechanisms, and that this kind of governance enables constant reconstruction of career guidance.
\end{abstract}

Keywords governmentality $\cdot$ self-improvement $\cdot$ evidence-based policy · technologies of government $\cdot$ feedback

\section{Introduction}

Today national career guidance policies in European countries and transnational networks are in varying ways designed in accord with the current European policy to reform existing career guidance in Europe (Frübing 2013). The objective of European career guidance policy is not to establish uniform career systems in Europe but to coordinate them towards mobility and flexibility (Council of the European Union

\footnotetext{
A. Bengtsson $(\bowtie)$

Stockholm University,

S-106 91 Stockholm, Sweden

E-Mail: anki.bengtsson@edu.su.se
} 
2004, 2008). Coordination is not compulsory; instead a commitment to comparison is mobilised which facilitates control of career guidance systems. In Lifelong guidance across Europe: reviewing policy progress and future prospects it is formulated:

A shared key challenge to the Member States is to determine common guidelines and principles for improving, assessing and measuring the efficiency of guidance systems and the institutions responsible for actual service provision. Further, there is a need to develop a more sustainable and transparent evidence base to support the policy design, especially from the perspectives of quality assurance, outcomes and cost-effectiveness of guidance service delivery (CEDEFOP 2011, p. 108).

In a broad sense, career guidance is related to employment and education, and it is around these issues policy for reconstruction of European career guidance can be made conceivable for intervention. Current European career guidance policy has been studied from actual policy steps and their linkage to European education and training programmes (McCarthy 2007). Another study focuses on implementation and evaluates the effectiveness of career guidance programmes and their effects (Whiston and Buck 2008). Drawing on insights from Michel Foucault's analytics of how to govern (Foucault 1991), the current paper takes another strand, namely to examine the ways by which European career guidance is rendered governable. The purpose of this article is to make theoretical sense, from a governance perspective, of governmental reason and mechanisms and procedures which operate in the policy process of reshaping career guidance. This investigation is restricted to European career guidance policy as it is enunciated in texts. It omits an observation of policy enactment, that is, realisation (in contrast to merely implementation) of policy in a specific environment and situation (Ball et al. 2012). Drawing empirically on European policy texts, this article examines policy use of "good practice" and provision of data, which is a method assumed to encourage learning. Moreover, attention is drawn to techniques of governance such as monitoring, evaluation and feedback which is typical of contemporary managerial forms of control through audit (Power 1994). My investigation seeks to illuminate the work of evaluating instruments and intellectual technologies in strategies for producing efficient and effective career guidance.

To date, the above described angle to study governance has been underestimated in career guidance research. However, research literature in education has investigated use of data in standardising academic assessment on reliance on service and policy use of statistics to legitimise policy (Ozga 2009). One example on this point is comparative studies such as the Survey of Adult Skills (OECD 2013) in which data is used to support policy measures. Another approach to governance pays attention to policy use and provision of data to motivate policymakers, practitioners and citizens to take some kind of action (Decuypere et al. 2011). A telling example of this procedure is to identify so called "good practices" in European reviews on national career guidance. The current paper examines policy use of "good practice" and provision of data, which is transformed into evidence, and it is therefore connected to evidence-based policy discourse (ibid.). From an epistemological lens, evidence discourse could be regarded as a specific regime of truth in which some ways of speaking and acting are made possible and others are downplayed (Foucault 1982a). 
After introducing the theoretical approach and considering its relation to analysis of policy discourse, I describe mediating instruments and circulation of information which support the emergence of a space of comparison of career guidance in Europe. Thereafter, the study draws empirically from policy texts and scrutinises policy use of data and instruments for evaluation which operate in the shaping of standards of improvement career guidance. It is followed by a discussion of the thoughts and practices which underpin the political strategy for reconstruction of career guidance. This paper seeks to contribute to existing research (see e. g. Bergmo-Prvulovic 2014; Käpplinger and Robak 2014) applying the governmentality perspective to understand contemporary forms of governance of career guidance.

\section{Analytical approach}

This study analyses political power from Foucault's notion of governmentality which focuses on questions of the modes of governing and how much, and by which thoughts of how to govern in a specific historical time and space (Foucault 1991). According to Foucault (1982b, pp. 788 et seq.), government is not imposed upon others; instead it implies freedom to act and power is exercised indirectly in an interrelated process of governing of others and governing the self, which operates as "conduct of conduct" (Foucault 1982b). This kind of governmental rationality operates by technologies of government which mediate thoughts and deploy diverse mechanisms which can be acted upon (Miller and Rose 2008, p. 32). The concept of technology is understood in a broad sense and comprises intellectual technologies (including texts) and technologies of the self. The latter is a form of conduct which acts upon self-regulating dispositions of the subject, which here refers to both the individual and the collective subject (Foucault 1988, 1991).

The governmentality perspective allows me transgress levels and focusing on operations which enable the linkage of political strategies for career guidance at one place and action in another. In this regard, study of policy extends the field. It is targeting and comprises a wider examination of the ways by which intervention and regulation is made possible. Consequently, attention is drawn to subtle mechanisms which can be located in instruments (e. g. indicators, reference tools), and discursive practices (e. g. common vocabulary, feedback and learning activities) (Rose 1999, p. 198).

Policy is based on ideas and assumptions about how the society should be regulated. In line with other governmentality studies in the field of educational policy (e. g. Fejes 2014; Forneck and Wrana 2005; Simons 2007, 2014), I scrutinise the complex of governance by which career guidance systems are made amenable for management. In particular, attention is paid to connections of intellectual technologies and instruments which deploy actions to motivate, facilitate, differentiate, and control the activities of subjects. This approach allows me to pose questions on the discursive formation in which the condition of truth-claims on career guidance are defined. My analytic method is to track components which visualise, deploy and arrange information on career guidance and examine in which actions they function in policy formation of career guidance. By this method, I detect patterns of regula- 
tive practices and how they connect with each other. Further, reading policy texts at the surface, I analyse assumptions of improvement and self-improvement; which thoughts that motivates them and by which mechanisms they get legitimised.

\section{Construction of a space for a political strategy}

The European member states have agreed upon two Council resolutions which seek to establish more systemic career guidance and to better integrate career guidance to lifelong learning (Council of the European Union 2004, 2008). As previously mentioned, the agreement has no binding rules and no sanctions; in their place are technologies of rule such as mutual learning, interdependence and peer pressure (Borrás and Jacobsson 2004). Thus, intellectual technologies operate in a process of fabrications of the role of career guidance in relation to certain objectives.

A specific instrument for the development of systemic career guidance is the Open Method of Coordination (OMC), which consists of tools for implementation, such as establishing indicators and benchmarks as means of comparing best practices, and periodic monitoring, evaluation and peer review as a mutual learning process (European Council 2000, paragraph 37). These tools work upon national and transnational collaboration in the politics of European integration and mobility. However, the tools are not unique for European Union, but similar components are used in models for standards (e. g. on quality) in national career guidance system (Niedlich et al. 2007). The OMC has rendered much research. In the field of education, authors suggest that the European Higher Educational Area (EHAE) and the Bologna Process are expressions of the OMC (Olsson et al. 2015), which, it is argued, produces particular technologies for establishing a space of comparison (Lawn and Grek 2012). Space is understood not as a bordered territory, but as a discourse or a scheme of relations within which imaginaries of the global and Europe are made real (Nóvoa 2015). In accord with above mentioned studies, the present study considers the OMC as machinery for construction of a space for calculation in terms of a political strategy. The regulative power within the OMC shapes specific selections of what is considered to be important and reasonable within a particular policy process. The OMC aligns elements and concepts from diverse fields; for instance, benchmark can be traced to business, indicators to statistics and peer review to science. Rearranged within a space for comparison and control, these concepts transform into social techniques to connect places and actors (Larner and Le Heron 2002).

The above mentioned abstract space for policy enables information to flow in multiple directions to be enacted and translated for further circulation, for instance within transnational and national forums (e. g. the German National Guidance Forum in Education, Careers and Employment). Information feedback on policy is gathered by expertise at various agencies (e. g. the European Lifelong Guidance Policy Network, ELPGN, the European Centre for the Development of Vocational Training, CEDEFOP, and the Organisation for Economic Co-operation and Development, OECD) and consultant firms or clearinghouses guidance (e. g. the Danish Clearinghouse for Educational Research, http://edu.au.dk/en/research/research-areas/danishclearinghouse-for-educational-research/). Educational research has investigated the 
complex relationship between public and private policy actors to define reforms in education, but here is not the place to pursue this issue (Hogan et al. 2015). Instead, attention is directed to the role of expertise, which is not merely to gather information but to reorganise texts and indicators, which are combined with data from other domains in the design of further texts and monitoring. Consequently, policy texts such as reviews, handbooks and kits for policymaking, questionnaires, guidelines, indicators and glossary are not only dissemination of information, but fabricated bodies of data which are assembled in a particular way as facts. In this way, policy discourse organises a specific way to think of career guidance, its role and function. This is further elaborated in the next chapter.

\section{Reconstruction of career guidance: evaluation, feedback and provision of data}

Policy continuously reviews whether national career guidance systems meet the objectives of better improvement and the agreed upon priority to develop career guidance (Council of the European Union 2008, p. 6). The rationale of improvement, according to policy, is better performance. The routines of monitoring and evaluation attempt to make member states accountable for learning from data and generate performance. This strategy is articulated in the policy questions posed to monitoring and evaluation respectively: "Are we doing things right?" and "Are we doing the right things?" (ELPGN 2014, p. 12). These questions indicate that "things" already exist and it is actual career guidance which is evaluated; whether its function fits to objectives or must be enabled. This governmental reasoning is underpinned by the monitoring-evaluation complex, which operates in a loop of feedback information and allows for estimation of "retrospective judgment on policy's success" as well as "inform the design and implementation of new policies" (ELPGN 2014, p. 24). In a similar vein, the German project The Open Process of Coordination for Quality Development (2009-2012) consists of six phases which end with "the development targets are assessed once again on the basis of the results and further measures, broader or new targets are agreed-the circle is closed, and a new round of quality development may begin" (nfb \& IBW 2012, p. 10). Thus, the term quality is not a fixed, but what is considered as quality emerges within the policy process and becomes temporarily stabilised as "facts" (Decuypere et al. 2011, p. 128 et seq.).

Monitoring and evaluation of policy are not tools that stand for themselves, but the policy process involves various incitements for actions. Two kinds of incitements can be identified within European career guidance policy: procedures for comparison of performance and provision of data for learning improvement. Comparison towards targets and standards informs one policy document formulation of performance improvement:

Member States now have at their disposal a vast array of comparative data against which they can benchmark themselves and their services. They also have several case studies of successful responses to the challenges that most countries are facing in their attempt to develop a guidance system that serves 
well both the public and the private good. Further, they have a set of practical common reference tools for designing and improving lifelong guidance systems and policies (CEDEFOP 2008, p. 67).

However, behaviour and attitudes to improvement involve other mechanisms such as mutual learning which invokes the readability for change among member states, decision-makers and career guidance practitioner. Activities for mutual learning and sharing experience are incitement for learning to judge the needs of change (or not) within an organisation or in this case programme of restructuring career guidance systems. Discourse of learning appeals to personal self-reflection on whether one's action is efficient in relation to improvement outcome.

Assessment of effectiveness of career guidance is rarely measured by numbers, which are based on accuracy. Instead, policy identification of "good practice" serves as indicator of success and deficits of improvement. Policy provision of "good practice" displays an imagination of difference of improvement and that someone is "doing" career guidance better. This imagination urges member states and decisionmakers to learn why and how some of them are capable to mobilise resources to deliver what is pronounced as effective career guidance. Further, circulation of "good practices" mediates feedback information to member states on their position in comparison to others. In accord with the method to define success and deficits, policy reviews of progress identify "gaps" of performance in relation objectives and timetables (e. g. CEDEFOP 2008; NICE 2012).

Similarly to "good practice", policy shapes "best evidence" as an indicator of assessment of what is central in evaluation of career guidance. Construction of specific evidence of career guidance is categorised by discourse of efficiency pertinent to certain goals in a specific context. In one research paper on an online professional resource in United Kingdom, evidence-based policy is coupled with impact and the goal is "to design services that reach ever-increasing numbers of people in a costeffective and efficient way" (Hughes and Graiton 2009, p. 7). Further, policy design of specific evidence through use of existing research is assumed to bridge the gap between policy, research and professional practice. It is formulated: "There seems to be an uneasy relationship between policy, practice and research. The findings of research studies are not always pertinent to the problems of guidance practitioners or of much practical value in policy-making" (CEDEFOP 2011, p. 108). Congruent to this statement, the report Evidence Base on Lifelong Guidance (ELPGN 2014) gathers a large number of diverse research studies on actual career guidance which are divided by their capacity to bring about specific evidence on efficient career guidance policy and practice. This capacity involves the ordinary practice of career services, which is anticipated to ensure "a culture of data gathering, use of client feedback, and continuous service improvement, which can provide a good baseline for research studies and national evaluations" (ELPGN 2014, p. 59). Thus, Construction of an evidence-based policy on career guidance appears to start from learning from actual career guidance.

From the above, it can be distinguished two modes of governing performance improvement in career guidance: by monitoring/evaluation and by use and provision of data. The next chapter will briefly elaborate upon thoughts which underlie the complex of governing career guidance and its limits. 


\section{The strategy of control}

Subtle regulative elements of motivating and evaluating actions of improvement and self-improvement can be situated in a strategy of control which implies that actors, such as member states, respond to assumptions of the capacity to control one's own performance of improvement. This strategy will be depicted by drawing attention to two mechanisms: establishment of a space of comparison and impetus for learning. First, the assumption that career guidance can be measured in relation to performance is supported by performance indicators and provision of examples of good practice (Simons 2007, p. 536). These mechanisms make national career guidance performance visible and comparable. It is a procedure which gives an impression that improvement is possible and motivates self-knowledge and self-improvement.

Second, policy use of examples of good practice and feedback on actual career guidance work as statements of success and what needs to be changed and improved and invoke to better performance. Also the loop of monitoring and evaluation, which is constantly there, at a distance, is part of concerting where and which things that should be changed and by whom. By these mechanisms, the possible is made concrete. The shaping of the possible start from a constructional view based on what is known and what has proven to work in existing career guidance in a specific context. In other words, the potential is not thought of in terms of normative ideas of progress, but it is estimated in relation to the actual performance. As a consequence, techniques of improvement of career guidance operate within the gap between the actual performance and optimal performance. It is assumed that motivation of learning can bridge this gap and modify agents' (member states) attitudes and aspirations of selfimprovement (Simons 2014, pp. 5 et seq.). The broad concern with self-improvement is linked with learning. Activities of mutual learning and sharing experiences encourage the capacity of learning and to communicate learning. In organisational learning, this procedure works upon a learning attitude and to find other ways of doing things better (Karlöf et al. 2001, pp. 3 et seq.). It is a form of learning integrated to efficiency, which invokes self-reflection on taking control of one's own operations. The above described modes of governance are directed towards responsibilisation of the organisation of career guidance and actors (member states, decision-makers, practitioners) within the field of career guidance; to make them use provided examples and instrument and activate their learning capacity.

\section{Conclusion}

The purpose of this article was to make theoretical sense of rationalities and the complex of mechanisms by which European career guidance is governed. Instruments such as the cyclical process of monitoring, evaluation and feedback are part of this complex, but likewise policy use and provision of data. These mechanisms support the underlying rationale of the governmental strategy that career guidance can be administrated more efficiently. This is a managerial strategy which is oriented towards better improvement performance. What can count as optimal performance is constructed from activities in existing career guidance system and assumptions 
of improvement made up from specific internal standards of efficiency. However, to achieve standardisation is not a closing end; rather, the complex of mechanisms for making career guidance amenable for management is directed towards constant learning for improvement and self-improvement. This form of governance opens for ceaseless reconstruction of career guidance systems.

Drawing on Foucault's (1982b) thoughts of governing by actions to act upon, this study has emphasised the importance of mechanisms with a double impetus: learning and change. It has been shown that stimulating learning seeks to motivate actors to manage change (what can be changed or not) and to inscribe a sense of control of needs and what works or not (Simons 2014). Policy conceptualisation of learning is connected to efficiency, which can be regarded as an effect of the governmental strategy that takes its form of performance improvement and continuous change. How learning is enacted in different ways in diverse settings is an issue that could be addressed by further research.

Open Access This article is distributed under the terms of the Creative Commons Attribution 4.0 International License (http://creativecommons.org/licenses/by/4.0/), which permits use, duplication, adaptation, distribution, and reproduction in any medium or format, as long as you give appropriate credit to the original author(s) and the source, provide a link to the Creative Commons license, and indicate if changes were made.

\section{References}

Ball, S. J., Maguire, M., \& Braun, A. (2012). How schools do policy: Policy enactments in secondary schools. London: Routledge.

Bergmo-Prvulovic, I. (2014). Is career guidance for the individual or for the market? Implications of EU policy for career guidance. International Journal of Lifelong Education, 33, 376-392.

Borrás, S., \& Jacobsson, K. (2004). The open method of co-ordination and new governance patterns in the EU. Journal of European Public Policy, 11, 185-208.

CEDEFOP - European Centre for the Development of Vocational Training. (2008). From policy to practice: a systemic change to lifelong guidance in Europe (Cedefop Panorama series 149). Luxembourg. http://www.cedefop.europa.eu/en/publications-and-resources/publications/5182. Accessed 15 Jan 2015.

CEDEFOP_European Centre for the Development of Vocational Training. (2011). Lifelong guidance across Europe: reviewing policy progress and future prospects (Working paper no. 11). Luxembourg. http://www.cedefop.europa.eu/en/publications-and-resources/publications/6111. Accessed 15 Jan 2015.

Council of the European Union. (2004). Resolution of the Council and of the representatives of the Member States, meeting within the Council, on strengthening policies, systems and practices in the field of guidance throughout life in Europe (9286/04. EDUC 109 SOC 234). Brussels. http://ec.europa.eu/ education/policies/2010/doc/resolution2004_en.pdf. Accessed 15 Jan 2015.

Council of the European Union. (2008). Resolution of the Council and of the representatives of the Member States, meeting within the Council, on better integrating lifelong guidance into lifelong learning strategies (15030/08. EDUC 257 SOC 653). Brussels, 20 November 2012. http://register.consilium. europa.eu/pdf/en/08/st15/st15030.en08.pdf. Accessed 15 Jan 2015.

Decuypere, M., Simons, M., \& Masschelein, J. (2011). "Perform, measure accurately, optimise": on the constitution of (evidence-based) education policy. International Studies in Sociology of Education, 21, 115-135.

ELPGN-European Lifelong Guidance Policy Network. (2014). The evidence base on lifelong guidance. $\mathrm{http}$ //www.elgpn.eu/publications/browse-by-language/english/elgpn-tools-no-3.-the-evidence-baseon-lifelong-guidance. Accessed 15 Jan 2015. 
European Council. (2000). Presidency conclusions. Lisbon, 23-24 March. http://www.europarl.europa.eu/ summits/lis1_en.htm. Accessed 15 Jan 2015.

Fejes, A. (2014). Working with Foucault in research on the education and learning of adults. In M. Milana \& J. Holford (Eds.), Adult education policy in the European Union. Theoretical and methodological perspectives (pp. 109-129). Rotterdam: Sense Publishers.

Forneck, H., \& Wrana, J. (2005). Ein parzelliertes Feld. Eine Einführung in die Erwachsenenbildung. Bielefeld: W. Bertelsmann.

Foucault, M. (1982a). The archaeology of knowledge and the discourse on language. New York: Vintage books.

Foucault, M. (1982b). The subject and power. Critical Inquiry, 8, 777-795.

Foucault, M. (1988). Technologies of the self. In L. H. Martin, H. Gutman \& P. H. Hutton (Eds.), Technologies of the self (pp. 16-49). Amherst: Tavistock Publications.

Foucault, M. (1991). Governmentality. In G. Burchell, C. Gordon \& P. Miller (Eds.), The Foucault Effect: Studies in Governmentality (pp. 87-104). London: Harvester Wheatsheaf.

Frübing, J. (2013). Developing quality of career guidance services: the German approach of open coordination and its international context. Career Designing-Research and Counselling, 2, 76-99.

Hogan, A., Sellar, S., \& Lingard, B. (2015). Network restructuring of global edu-business: The case of Pearson's efficacy framework. In W. Au \& J. J. Ferrare (Eds.), Mapping corporate education reform: Power and policy networks in the neoliberal state (pp. 43-64). London: Routledge.

Hughes, D., \& Gration, G. (2009). Evidence and impact: Careers and guidance-related interventions. Introduction to an online professional resource (Research Paper). CfBT Education Trust. http:// www.eep.ac.uk/DNN2/Portals/0/IAG/E\&I\%28Synthesis\%29 FINAL\%28W\%29.pd. Accessed 26 May 2015.

Käpplinger, B., \& Robak, S. (Eds.). (2014). Changing configurations of adult education in transitional times. Frankfurt a. M.: Peter Lang.

Karlöf, B., Lundgren, K., \& Froment, M. E. (2001). Benchlearning: Good examples as a lever for development. Chichester: John Wiley. and sons.

Larner, W., \& Le Heron, R. (2002). The spaces and subjects of a globalising economy: a situated exploration method. Environment and Planning D: Society and Space, 20, 753-774.

Lawn, M., \& Grek, S. (2012). Europeanizing education: Governing a new policy space. Oxford: Symposium books.

McCarthy, J. (2007). Catapulted to the front: Career guidance in European Union and international policy perspectives. Report. Zeitschrift für Weiterbildungsforschung, 30(4), 3-50.

Miller, P., \& Rose, N. S. (2008). Governing the present: Administering economic, social and personal life. Cambridge: Polity.

$\mathrm{Nfb}$ - Nationales Forum Beratung in Bildung, Beruf und Beschäftigung \& IBW (Forschungsgruppe Beratungsqualität am Institut für Bildungswissenschaft der Ruprecht-Karls Universität Heidelberg). (2012). Quality and professionalism in career guidance and counselling - The open process of coordination for quality development in career guidance in Germany (2009-2012), English Short Version of Main Results. Berlin/Heidelberg. http://www.beratungsqualitaet.net/upload/Servicenavigation/ bersetzung_BQ_Druckfreigabe.pdf. Accessed 26 May 2015.

NICE - Network for Innovation in Career Guidance and Counselling in Europe. (2012). Handbook for the Academic Training of Career Guidance and Counselling Professionals. http://www.nicenetwork. eu/fileadmin/erasmus/inhalte/bilder/meine_Dateien/NICE_Handbook/NICE_Handbook_full_version_online.pdf. Accessed 15 Jan 2015.

Niedlich, F., Christ, F., Korte, I., Berlinger, U., \& Aurich, P. (2007). Bestandsaufnahme in der Bildungs-, Berufs- und Beschäftigungsberatung und Entwicklung grundlegender Qualitätsstandards. Abschlussbericht. Beauftragt vom Bundesministerium für Bildung und Forschung. Hamburg. http:// www.bmbf.de/pubRD/berufsbildungsforschung.pdf. Accessed 26 May 2015.

Nóvoa, A. (2015). Knowledge as politics. Traveling with Tom Popkewitz. In M. Pereyra \& B. M. Franklin (Eds.), Systems of reason and the politics of schooling. School reform and sciences of education in the tradition of Thomas S. Popkewitz (pp. 207-219). London: Routledge.

OECD-Organisation for Economic Co-operation and Development. (2013). OECD skills outlook 2013: First results from the Survey of Adult Skills, OECD Publishing. http://dx.doi. org/10.1787/9789264204256-en. Accessed 15 Jan 2015.

Olsson, U., Petersson, K., \& Krejsler, J. B. (2015). On confessional dialogue and collective subjects. In A. Fejes \& K. Nicoll (Eds.), Foucault and a politics of confession in education (pp. 93-105). London: Routledge. 
Ozga, J. (2009). Governing education through data in England: From regulation to self-regulation. Journal of Education Policy, 24, 149-62.

Power, M. (1994). The audit explosion. Oxford: Oxford University Press.

Rose, N. (1999). Powers of freedom: Reframing political thought. Cambridge: Cambridge University Press.

Simons, M. (2007). "To be informed": Understanding the role of feedback information for Flemish/European policy. Journal of Education Policy, 22, 531-548.

Simons, M. (2014). Governing education without reform: the power of the example. Discourse: Studies in the Cultural Politics of Education, April, pp. 1-20.

Whiston, S. C., \& Buck, I. M. (2008). Evaluation of Career Guidance Programs. In J. A. Athanasou \& R. Esbroeck (Eds.), International handbook of career guidance (pp. 677-692). Dordrecht: Springer. 